\title{
OVERCOMING SPOILED CHILDREN WITH NATURAL APPROACHMENT
}

\author{
MENGATASI SIFAT ANAK MANJA DENGAN PENDEKATAN ALAMIAH
}

\author{
Daviq Chairilsyah \\ Teacher Education of Early Childhood Education Study Program, Universitas Riau, Pekanbaru 28293, Indonesia. \\ email: daviqch@yahoo.com
}

\begin{abstract}
Spoiled is the attitudes and actions of children obtained from the environment such as family environment, community environment, and school environment. These things can affect children to not to have selfreliance to learn and to do things optimally. In overcoming the children indulgence, parents should know the factors that cause it. Several factors cause children to be spoiled can come from the family, community and school. Through this literature review, the author tries to propose some good and planned strategies that can be carried out by the teacher and parents. Parents and teachers can do various activities so that children are stimulated to do their activities. Teachers can also approach directly and work closely with children's parents in creating children's independence programs. Tips for parents to deal with spoiled children are consistent with parents mean what they say as it builds credibly, provide explanations that are easy for children to understand about independence in everyday life, show and explain good and bad behaviour in children. Besides, parents must consistently give punishment and praise to children if they succeed or violate the rules regarding self-reliance, and involve children in various social activities so that children can learn to share, communicate and control his ego.
\end{abstract}

Keywords: Children, Spoiled, Self-Reliance.

\begin{abstract}
ABSTRAK
Manja adalah sikap dan perbuatan anak yang diperoleh dari peran lingkungan baik lingkungan keluarga, lingkungan masyarakat, dan lingkungan sekolah yang akan mengakibatkan anak tidak punya kemandirian untuk belajar dan untuk melakukan sesuatu secara optimal. Dalam mengatasi kemanjaan anak sebaiknya orang tua mengetahui faktor penyebab kemanjaan anak tersebut. Ada beberapa faktor penyebab anak menjadi manja bisa berasal dari lingkungan keluarga, masyarakat, dan sekolah. Melalui kajian literatur ini penulis mencoba mengajukan beberapa strategi yang baik dan terencana yang dapat dilakukan oleh guru dan orangtua. Orangtua dan guru dapat melakukan berbagai kegiatan supaya anak terangsang untuk melakukan kegiatan sendiri. Guru juga dapat melakukan pendekatan secara langsung dan bekerjasama dengan orangtua anak dalam membuat program kemandirian anak. Tips bagi orangtua untuk mengatasi anak yang manja adalah konsisten dengan apa yang orangtua katakan, memberikan penjelasan yang mudah dimengerti anak mengenai kemandirian dalam keseharian, menunjukkan dan menjelaskan perilaku yang baik dan buruk pada anak. Selain itu juga orang tua harus konsisten memberikan hukuman dan pujian bagi anak apabila berhasil atau melanggar aturan mengenai kemandirian, dan libatkan anak dalam berbagai kegiatan sosial agar anak dapat belajar untuk berbagi, berkomunikasi, serta mengontrol egonya.
\end{abstract}

Kata kunci: Anak, Manja, Kemandirian.

\begin{tabular}{|c|c|c|c|}
\hline First Received: & Revised: & Accepted: & Published: \\
26 September 2019 & 04 October 2019 & 0ctober 2019 & October 2019 \\
\hline
\end{tabular}




\section{INTRODUCTION}

Spoiled is the attitudes and actions of children obtained from the environment such as the family environment, community environment, and school environment (Muslich, 2011). It will result in children not having self-reliance to learn and to do something independently. Thus, the children will always depend on others to do something for future development and cannot achieve more optimal results (Koesoema, 2010).

Motivation and the role of the environment greatly influence the children development in carrying out something that does not deviate from the rules of the children like themselves. The role of the family is the main role which is very important so that the children do not act spoiled, then the other role of the community environment and strengthened by the role of teachers in schools to anticipate the emergence of childhood (Umari et al, 2018).

Preschool age is the right time to train the children self-reliance. By entering this period, the children can catch the parents' wishes and the children self-reliance will gradually form after socializing with their friends at school (Hasan, 2012). The level of self-reliance of the children is usually influenced by several factors including attitudes of parents, the environment, parental demands, habits at home, activities outside and inside the house, and the role of family members (Hasan, 2012). Fadillah et.al (2014) adds that the above factors influence the formation of children personality and emotions. One form of parental attitudes as one of the factors that influence the level of self-reliance of children that we often see in the current era is the number of mothers who work to meet the socio-economic needs of the family or just meet career demands.

The problems that often arise as a result of working mothers are that the children's desires are always obeyed, children are freer to do activities, children can solve their problems and tend to have higher ideals (Kantjono, 2001). Whereas children with mothers who do not work are more likely to be assisted at-home activities, the attitude of parents is always protective, too worried, children are more bound in all things, activities of children outside the home are less so that children are less able to solve problems that arise (Prabaningrum, 2013). These conditions can have a direct or indirect impact on children's self-reliance, such as limited children's activities, children are often afraid of making choices.

Efforts that can be used in the development of children's self-reliance are the active role of parents in creating a home environment as the first social environment experienced by children so that children are gradually able to free themselves from dependence and absolute protection from their parents (Istiqomah, 2004). Parents can develop balanced affection by allowing children to show their affection.

Preschool period according to Rustini (2012) is a time to play and start entering kindergarten. Playtime is a means to grow in the environment and its readiness informal learning with a preschooler age limit that is between the ages of 1 to 6 years. At the stage of development of preschoolers, children begin to master a variety of physical skills, language, and begin to have the confidence to explore their self-reliance. The development team of the Elementary Education Course 
(MKDK) believes that in preschool there will be a very strong urge to demand selfrecognition. Their will must always be obeyed and their emotions are often overflowing accompanied by aggressive behaviour that is very strong, especially if their desires are not obeyed. At this condition, the children will consciously want to escape from the influence of their mother and want to stand alone, because it is driven by a positive and strong passion for life. The development of preschool children is related to the level of self-reliance. Self-reliance is the main characteristic of preschoolers. Besides, mastering motoric skills, cognitive skills and language make them confident in experiencing the process of growth and development so that children become independent (Sudarna, 2014).

\section{Theoretical Review}

Fathurrohman et.al (2013) states that Spoiled child is a child who always expects excessive attention from the environment around him, also followed by a desire to and obeyed all his wishes. Not a few parents who have done this without realizing it, for example, parents who are always busy sometimes do compensation by spoiling children. Eventually, attitudes toward children become excessive. Children must be in an easy and pleasant atmosphere of life. Then all the attention and assistance is mobilized. Consequently, the children develop a personality to more easily " to accept" than "to give".

At school, the teacher is more directing, educating and motivating so that the children can change gradually and can optimally carry out learning activities by not behaving or being pampered. Spoiled nature of children is can also affect the delay of children doing learning activities in school. Furthermore, it will inhibit all activities carried out (Pidarta, 2013).

Wibowo (2012), states that when children need physical and spiritual needs, they will continue to learn together. If the children learn with a casual attitude, of course, it will get results that are less than optimal or less satisfying. Whereas the expected goal of learning is to achieve the learning objectives as optimal as possible. If schools and families give everything that leads to the children to be spoiled, then the children do not get and achieve goals optimally and the children do not have the independence to do something for the future progress (Marliany, 2014).

Sudaryanti (2012) states that spoiling a child means increasing his belief that he can always get what he wants, perhaps with anger or flattery or even by pitting one another. The characteristics of spoiled children include:

a. Cry and scream when they want something.

b. Often angry and even hit when parents/teachers punish them.

c. Be rude to adults and other children.

d. Refusing to share something or certain behaviour with other children.

e. Likes to show off, and always wants to be the centre of attention among the group.

f. Always want what others have if you have succeeded in having it.

g. Always want something new.

h. Demanding others to help him do something when he can do it himself. 
In general, the main factor that causes the spoiled nature of children is family environmental factors, namely in the form of parenting mistakes towards their children. Latif et.al (2013) said that only children, eldest, youngest, often abandoned by parents, and competition among children is the cause of children become spoiled in the family environment. The explanation is as follows:

1. An only child is often watched excessively. This attitude usually occurs because parents are afraid of their child injured or missing. Consequently, the child will feel not free. Feeling not free will be realized by demanding his parents to obey his will.

2. The eldest is usually treated the same as an only child at first. In this case, parents usually try their best to fulfil all desires and bestow all the attention and affection for him. But after his sibling was born, the attention of the parents naturally shifted and was divided. At this time, the eldest feels jealous and tries to seize the love of his parents who began to wane by reacting in strange ways, such as crying, screaming and pretending to be sick. Because their parents feel guilty, eventually the eldest will be spoiled by parents.

3. The youngest child can be a spoiled child. This is because the youngest is still considered a child by his siblings. The pleasure of the youngest child is not only sourced from his parents but also his siblings.

4. Children who always suffer from diseases can also be spoiled children. Children who are always infected with diseases usually get special attention from their parents and siblings. This excessive attention can spoil a child.

5. A boy who lives among sisters also usually receive special attention from their parents. This condition can drive the boy to be a spoiled child.

6. Children who are often left behind by parents who are too busy also have the potential to become spoiled children. Usually, such parents will compensate for their lack of attention by spoiling their children and allowing whatever the children do and the children will do everything as they wish.

\section{METHODS}

Literature study or known as a literature review is a description of the theory, findings, and other research materials that are used as a basis for research activities in preparing the framework of the problem formulation. Another source said that the notion of literature review includes analysis in the form of both constructive and dropping criticism from research being carried out on specific topics. The contents of the review literature include summaries, reviews, and the writer's thoughts derived from library sources such as slides, articles, information from the internet. Good review literature is relevant and the most up to date. This is useful to support the topics discussed in the research. It also helps in limiting the problem (Sugiyono, 2015).

The understanding of literature according to experts is reading material that can be used in various activities, both intellectually and recreation (ALA Glossary of Library and Information Science (1983)). 
In general, literature comes from books or scientific journals, so it is authentic to be used as a source of reference. Literature is a basic material that can be used as a reference in writing scientific papers. Literature is not merely in the form of writing, it can also be in the form of nonbooks such as recordings, vinyl record, laser disks, films, tapes, etc that can provide information.

The literature review itself can be classified into primary literature and secondary literature, and tertiary literature. The sharpness of the analysis of each literature is different. Primary literature is the original written work which contains a theory or an idea in various fields, such as research reports, patents, dissertations, seminar papers and others. Meanwhile, secondary literature is literature that summarizes, or indexes primary literature, so it does not contain new literature. Tertiary literature contains instructions for obtaining secondary literature, such as directory bibliography (Sugiyono, 2015).

In this literature review, the author uses primary and secondary sources on the topic of spoiled nature and behaviour in early childhood. The author seeks to provide an understanding of the importance of this spoiled behaviour which can negatively affect early childhood development.

Besides, the author is also trying to provide opinions and suggestions for teachers and parents in educating spoiled children to become an independent person both at school and at home.

\section{RESULTS AND DISCUSSION}

Spoiled is not included in the pathology (disease is also a psychological disorder) but it would be bad if the excess is excessive, more so if it is supported by family or relatives. This will certainly cause the children to become dependent. Besides, it also allows the children to use their spoiled nature to get what they want. If a child is left by his parents, the child will become spoiled continuously (Chairilsyah, 2016). Indirectly, the selfish attitude and lack of sensitivity to the environment will be formed. In daily life association, the impact will be felt. Everyone must obey the wishes of the child or the child will sulk to get what the child wants. The concept of the child is also not good because the child becomes a person who is not trying and lack of motivation. This possibly happens if the child feels easy to get something or what the child wants (Suwartini, 2018).

In the initial stages of entering preschool or kindergarten, children are trained not to be spoiled. This can be seen when the learning process, children are no longer attended by the class by their parents. In the next stage, the children can understand and want to be independent in carrying out learning activities in school without having to be assisted by the teacher (Silahudin, 2017). Thus, the children are no longer dependent on the teacher or other people. In the needs of children, both physical needs and spiritual needs in children's learning need to be instilled and directed various efforts and ways so that there is no longer spoiled nature children 
(Rakhman, 2015). Here are some tips for teachers to deal with spoiled children:

1. Class regulation.

Make a kind of simple class regulation. One of them, "May not be accompanied by Mama or Papa in the class". Tell them at every meeting so that the children are motivated to be an independent child.

2. Parents do not run away.

We should avoid things that can make children feel uncomfortable, and anxious while in class. One of them is by asking parents to go out secretly without the children's knowledge.

3. Observing the developments.

If we see a student who still wants to be accompanied by his parents, we as a teacher should not worry. Do not let the first day of school, children become a bad day for students. Let them play and learn to be accompanied by their parents, while you continue to get acquainted, and foster good relations with the child. This is very important so that students feel comfortable in class, and we can become friends with students. A good impression at the beginning of the meeting will facilitate the next step.

4. Motivate each lesson.

Motivating students in every work is very important. This is closely related to the comfort of students in the classroom. Motivations can be given by compliments in every work completed by students, displaying work on the wall or school board, giving gifts when the child students complete their tasks, and much more.
5. Give praise.

Give "more" praise to students who are willing to learn in class independently. This can also be done to motivate children who are still accompanied by their parents so that they are infected to want to learn independently.

6. Communicate with parents.

Keep in communication with parents to develop good strategies so that the children can learn independently. Ask parents about things that children like and don't like. For example, if the children do not like to dance, the teacher does not force the children to dance.

7. Invite children to play outside the classroom.

Several children need several stages to make them comfortable in the school environment. To make students have beautiful thoughts about learning in school, invite them to play outside the classroom, playroom for example.

8. "Punish" parents.

"Punish" in this case, of course only in a literal sense. This we can do as an act of "challenging" for children. In this case, do not do it in a hard way, but it must be done in a gentle way accompanied by a humour.

9. Sing a song to motivate independent living.

Sing a song at each meeting. This is done so that in the hearts of students embedded the spirit to live independently. Sing songs with the theme of "independent children"

10. Take a temporary child off.

If there is no other way, leave the child for a few days. Let parents persuade children to want to go back to school. The 
child's emotions may not be good so it is difficult to accept the atmosphere and new things. Every child will find it easier to accept new things when he has a good heart condition.

Tips for parents to deal with spoiled children include:

1. Be consistent with what is said.

One of the things that often cause spoiled arises is parents are not consistent with what has been said to the child. When children ask for something they want and then parents say they can't fulfil it, then the child is more likely to whine or cry because they don't get what they want. Parents who see and hear the child cry start to be compassionate so that they give what they want. From this, children learn that they will get what they want if they whine or cry. Therefore, the child may whine louder if further requests are not complied with. If a parent does say "no" at the beginning, then keep the word no until the end, even if you have to see the child whining and crying. This is one test for parents whether they can be consistent with what has been said. If the child cries, then let it go or talk nicely to the child the reason why we cannot fulfil his request.

2. Provide explanations that are easy for children to understand.

When children ask for something and parents can't or don't want to fulfil it, then give them an explanation of why they can't get it. Children have the right to be angry, sad, and disappointed if their wishes cannot be fulfilled. But by giving a clear explanation to the child, it will help the child understand about the situation occurs. Then, he will be easier to overcome his sadness and can understand when he has to ask for it again.

3. Give praise.

When children do good things, give them praise even though the things they do are small. By continuing to praise it, the children will be motivated to do other kindness. Besides, parents can also give kisses and hugs when they are doing good. They are not only motivated to do other good deeds, but also feel their parents' love for them.

4. Involve children in various social activities .

By involving children in social activities, children will learn to share, communicate, and control their egos. Besides, parents can tell and explain various life lessons and moral values that are in the social group with language that is easy to understand. For example, parents can explain the meaning of being grateful, and so on.

5. Provide punishment.

Providing punishment is not always bad for children. Giving proper punishment to children will make children learn not to repeat bad things. For example, parents can confiscate their favourite items or toys when the child is not tidying up his room or bed.

6. Demonstrate and explain good and bad behaviour in children.

Telling good behaviour that children should do may already be a normal parent, but explaining every look at bad habits or bad behaviour that occurs around the children is another thing. For example, when parents go somewhere and see another child whining or 
throwing a tantrum for something, tell the children that this is a bad thing and explain the consequences that will occur if they do it.

7. Explain to the children that the contribution of each family member is needed to maintain the household.

Have the children to become volunteers or assign them to do work around the house such as make their beds, store their toys, and dress themselves. Remember, when children have something, it helps to meet their needs to have.

8. Give children an example of the behaviour expected of them.

If parents want their children to make their beds, parents also need to make their beds. If parents want children to clean themselves, then parents must do the same. If a parent wants children not to smoke, use drugs or alcohol, they should never see parents involved in these practices.

\section{CONCLUSION}

Dealing with the spoiled nature children, parents should know the causes of it. Several factors cause children to be spoiled such as the family, community and school. A good and planned strategy can be done by a teacher and parent. Parents and teachers can do various activities so that children are stimulated to do their activities. Teachers can also approach them directly and work closely with parents in creating children's independence programs. Children who can compete are children taught from an early age by parents and teachers have the opportunity to struggle in getting what they want in a positive way.

\section{REFERENCES}

Chairilsyah, D. (2016). Metode dan Teknik Mengajarkan Kejujuran Pada Anak Sejak Usia Dini. Jurnal Educhild,5 (1), 8-14.

Fadillah, M \& Khorida, L. M. (2014). Pendidikan Karakter Anak Usia Dini: Konsep dan Aplikasinya dalam PAUD. Jogjakarta: Ar-ruzz Media.

Fathurrohman, P., Suryana, AA \& Fatriany, F. (2013). Pengembangan Pendidikan Karakter. Bandung: PT. Refika Aditama.

Hasan, M. (2012). PAUD (Pendidikan Anak Usia Dini). Jogjakarta: Diva Press.

Istiqomah, U. (2004). Merawat dan Mendidik Anak. Surakarta: PT. Widya Duta Grafika.

Kantjono, A. T. (2001). Mengajarkan Emotional Intelligence pada Anak. Jakarta: PT. Gramedia Pustaka Utama.

Koesoema, D. (2010). Pendidikan Karakter. Jakarta: Grasindo.

Latif, M., dkk. (2013). Orientasi Baru Pendidikan Anak Usia Dini: Teori dan Aplikasi. Jakarta: Kencana Prenadamedia Group.

Marliany, R. (2014). Psikologi Umum. Bandung: Pustaka Setia.

Muslich, M. (2011). Pendidikan Karakter: Menjawab Tantangan Krisis Multidimensional. Jakarta: Bumi Aksara.

Pidarta, M. (2013). Landasan Pendidikan. Jakarta: Rineka Cipta. 
Prabaningrum, D. W. (2013). Menyiapkan Anak Untuk Sukses di Sekolah dan Kehidupan. Jakarta: PT. Indeks.

Rakhman, A. (2015). Kurikulum Pendidikan Anak Usia Dini Berbasis Pendekatan Antarpersonal (A Relationship-Based Approach).Jakarta: Prenadamedia Group.

Rustini. (2012). Pendidikan Karakter Anak Usia Dini. Jurnal Cakrawala Dini, 3 (1).

Silahudin. (2017). Urgensi Membangun Karakter Anak Sejak Usia Dini. Jurnal UIN Ar-Raniry,3(2), 18-41.

Sudarna. (2014). Pendidikan Anak Usia Dini Berkarakter. Yogyakarta: Genius Publisher.

Sudaryanti. (2012). Pentingnya Pendidikan Karakter Bagi Anak Usia Dini. Jurnal Pendidikan Anak, 1 (1).

Sugiyono. (2015). Metode Penelitian Kuantitatif, Kualitatif dan $R$ \& D. Bandung: Alfabeta.

Suwartini, S. (2018). Pengembangan Buku Ajar Pendidikan Karakter dengan Pendekatan Pembelajaran Berbasis Soft Skill Pada Siswa SD Kelas II. Jurnal Educhild, 7 (2), 102-106.

Umari, T \& Rosmawati. (2018). Analisis Nilai-nilai Karakter Cerdas Mahasiswa FKIP Universitas Riau. Jurnal Educhild, 7 (2), 118-126.

Wibowo, A. (2012). Pendidikan Karakter Usia Dini. Yogyakarta: Pustaka Pelajar. 